Papers and Proceedings of the Royal Society of Tasmania, Vo1.109, 1975.

(ms. received 21.11 .1974 )

\title{
A NEW SPECIES OF SAGITTA (CHAETOGNATHA) FROM D'ENTRECASTEAUX CHANNEL, TASMANIA
}

\author{
by Nyan Taw
}

\author{
Department of Zoology, University of Tasmania \\ (with one table and two text figures)
}

\begin{abstract}
A new species of the genus Sagitta (Chaetognatha), S. guizeri sp. nov. found in D'Entrecasteaux Channe1, Tasmania is described and figured. Its relation to $S$. neglecta Aida is discussed and its distribution in the south-east coastal waters of Tasmania is given.
\end{abstract}

\section{INTRODUCTION}

During a study of the zooplankton of the south-eastern coastal waters of Tasmania, an abundance of specimens of a species of Sagitta were collected in the northern parts of D'Entrecasteaux Channe1, southern Tasmania. These specimens differ from all known species and are considered to represent a new species for which the name Sagitta guileri sp. nov. is proposed. The species is named in honour of Dr. E.R. Guiler, Reader in Zoology, University of Tasmania.

\section{DESCRIPTION OF SPECIES}

Sagitta guileri sp. nov.

(figs. $1 \mathrm{a}-\mathrm{g}$ )

Type Material

Holotype, paratypes 10; Tasmanian Museum Registration Nos. K762 - K763. Taken in a midwater $(10 \mathrm{~m})$ plankton tow during the night of 22 nd December 1971 , off Barnes Bay, Bruny Island, D'Entrecasteaux Channe1, Tasmania.

Description

Body length, $8.0-10.5 \mathrm{~mm}$ based on 25 mature (stage IV) specimens.

Body rigid and opaque in formalin preserved specimens; length of fully mature (stage IV) specimens reaches to $10.5 \mathrm{~mm}$; head is of normal size, approximately equal to the widest region (mid region) of the body; hooks totally concealed if viewed from dorsal side of head; eyes rounded with the pigmented area well developed and in the form of letter ' $T$ ' lying sideways with the top part pointing laterally; intestinal diverticulum present but not obvious; corona ciliata absent.

Tail region forms between 25.5 and $29.6 \%$ of the total body length (excluding the tail fin); the number of hooks may be 6 or 7 ; the number of anterior teeth is either 4 or 5 ; there are between 6 to 9 posterior teeth.

Collarette present, extending from head to tail region as far as middle region of the tail fin; relatively thicker at the neck and the vicinity of seminal vesicles.

Anterior fin begins at a distance (approximately $4.0 \%$ of the body length) behind posterior end of ventral ganglion; elliptical in shape; shorter than posterior fin with the widest part at the middle region; entirely supported by rays.

Posterior fin long and situated more on tail region than on the body; completely 


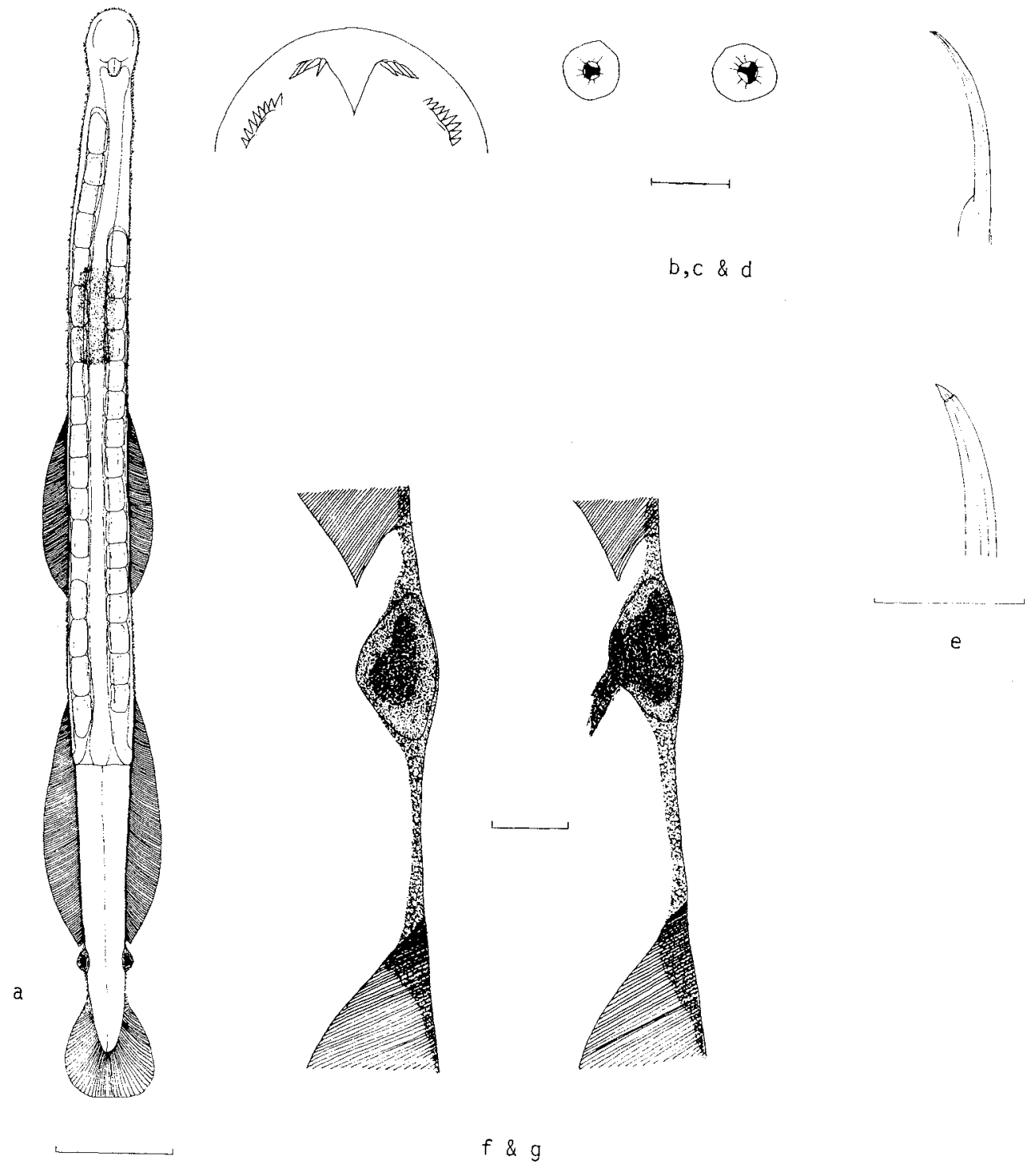

FIG. 1. - Sagitta guileri sp. nov.
a. Entire animal, ventral view (scale $1.0 \mathrm{~mm}$ long).
b. Ventral view of anterior region of the head showing anterior and posterior teeth (scale 0.1mn long).
c. Detailed structure of eyes (scale as b.).
d. Detailed structure of 3 rd right hook (counted from ventral side) (scale as b.).
e. Detailed structure of distal region of $3 \mathrm{rd}$ right hook (scale $0.05 \mathrm{~mm}$ long).
f. Mature seminal vesicle (scale $0.1 \mathrm{~mm} 1 \mathrm{ong}$ ).
g. Mature seminal vesicle (bursting) (scale as f.). 
Nyan Taw

supported by rays; posterior end terminates just in front of anterior tip of seminal vesicles.

Ovaries long, one on each side reaching up into the neck region; ova rounded and large, in one row, filling the body cavity.

Seminal vesicles situated near posterior fin; roundish to triangular in shape with the protuberance at the mid-lateral region; bursting at the protuberance (midlateral edge) when mature.

\section{DISTRIBUTION}

S. guizeri sp. nov. was very abundant in the northern parts of the D'Entrecasteaux Channe1. The maximum number collected in a tow was 1005 (72.9 specimens per cubic meter). It was captured usually during night tows and found to be abundant from November to January. During the remaining months the number observed was low (less than 1.2 /cubic meter).

A 1arge number of inshore and offshore coastal zooplankton samples have been studied. However, $S$. guileri sp. nov. was found only in the inshore waters. The localities of zooplankton stations sampled and those where $S$. guileri sp. nov. was encountered are shown in fig. 2 .

\section{DISCUSSION}

Sagitta guileri sp. nov. belongs to the 'neglecta' group (Tokioka and Pathansali 1963; Alvarino 1967) being most closely related to $S$. neglecta Aida. The main characters in which it can be distinguished from $S$. neglecta are: i) low number of posterior teeth; ii) position of anterior fin in relation to ventral ganglion; iii) extended length of ovaries; $i v)$ shape of seminal vesicles. In table 1 , characteristic features of $S$. guiteri sp. nov. are compared with those of $S$. neglecta Aida described by Michael (1911, 1919), Thomson (1947), Sund (1959), Tokioka (1959), and Alvarino $(1967)$.

The absence of the corona ciliata in $S$. guileri sp. nov. is one of the main features in which it differs from $S$. neglecta. However, this character is of small taxonomic value owing to the fact that the corona ciliata does not usually persist in $5 \%$ formalin preserved specimens (Alvarino 1967).

The number of posterior teeth in $S$. guileri sp. nov. is low compared with $S$. neglecta (table 1). Californian specimens of $S$. neglecta, apart from having a low number of posterior teeth, have the remaining characters agreeing with $S$. neglecta (Michae1 1911). Ritter-Zahony (1911) recorded the number of posterior teeth in his S. neglecta specimens from tropical waters of Indian and Pacific Ocean, as 12 to 18 in large specimens $(7-10 \mathrm{~mm})$.

Michael (1919) found in his Philippine specimens that three out of ten specimens he studied had the anterior fin beginning 1.0 to $1.5 \%$ of the body 1 ength behind the ventral ganglion. In the remaining specimens the anterior fin began at the ventral ganglion. Similarly, Alvarino (1967) described her specimens of $S$. neglecta from South China Sea and the Gulf of Thailand as having the anterior fin beginning a short distance behind the posterior end of the,ventral ganglion. From her figures (Alvarino 1967, p. 179, figs. 46A-D) it is evident that the anterior fin begins approximately $1.0 \%$ of the body length, behind the ventral ganglion. Ritter-Zahony (1911) reported that his $S$ : neglecta specimens had the anterior fin beginning just behind or a little way behind the ventral ganglion. In $S$. guileri sp. nov. the anterior fin begins approximately $4.0 \%$ of the body length behind the ventral ganglion. 


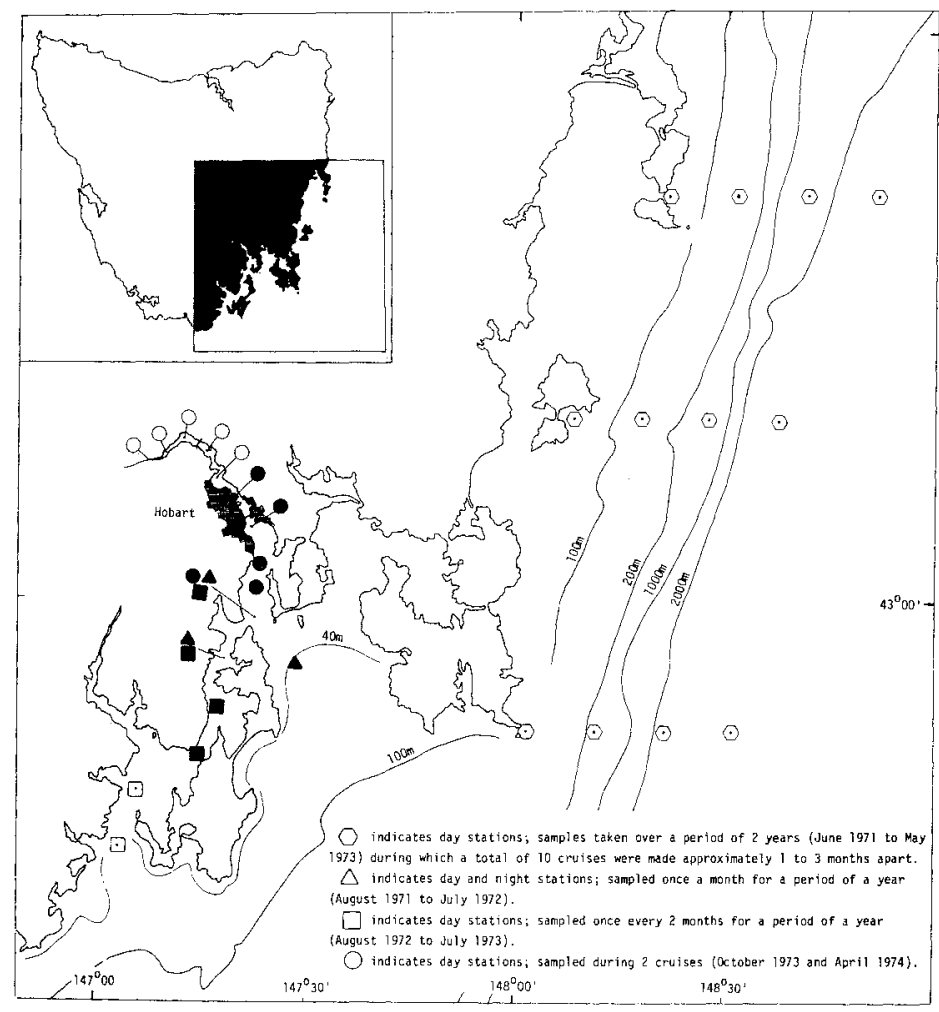

FIG. 2. - Zooplankton stations in the south-eastern coastal waters of Tasmania.

Solid symbols indicate stations where $S$. guileri sp. nov. was found; open symbols indicate stations where $S$. guiteri sp. nov. was not found.
The structure of ovaries and ova of $S$. guizeri sp. nov. is similar to that of $S$. negreata described by Alvarino (1967). However, in $S$. neglecta the ovaries reach up to midway between the neck and ventral ganglion whereas in $S$. guizeri sp. nov. they extend into the neck region.

The seminal vesicles of $S$. guileri sp. nov. differ from those of $S$. neglecta in shape (see table 1). The shape of the seminal vesicles of $S$. negrecta has been described by Alvarino and as claimed by Michael (1911) is similar to that of the seminal vesicles of $S$. serratodentata.

The relationship of S. guileri sp. nov. to material from south eastern Australia recorded (Thomson 1947) as $S$. neglecta is not clear (table 1). However, Professor Thomson, after examining material of the new species has expressed the opinion (personal communication) that "a careful comparison of $S$. guileri sp. nov. and recognised $S$.
neglecta from Port Hacking may well suggest consistent differences." Unfortunately, an attempt to obtain samples of this material for comparison with that described herein was unsuccessful.

\section{AC KNOWLEDGEMENTS}

Sincere thanks are due to the following: Dr. E.R. Guiler and Dr. J.L. Hickman for their encouragement and critically examining the manuscript; the skipper of the Zoology Department Research Vessel 'Neotrigonia', Mr. T. Sward, for his help in the field; Professor J.M. Thomson, Head of Zoology Department, University of Queensland, for examining the specimens and helpful comments; Mr. F.B. Griffith, Curator of Zooplankton, Division of Fisheries and Oceanography, C.S.I.R.O., Cronulla, for examining the specimens.

This work has been carried out while the author held a Colombo Plan Fellowship for which he is grateful. 
Nyan Taw

\section{REF ERENCES}

Alvarino, A., 1967: The Chaetognatha of the NAGA Expedition (1959-1961) in the South China Sea and the Gulf of Thailand. Pt. 1. Systematics. NAGA REP. 4(2), 1-195.

Michae1, E.L., 1911: C1assification and vertical distribution of the Chaetognatha of the San Diego region. Univ. Calif. Fubls Zool. 8(3), 21-170.

, 1919: Report on the Chaetognatha collected by the United States Steamer "Albatross" during Philippine Expedition, 1907-1910. U.S. Natn. Mus. Bulz., 100, 1(4), 235-77.

Ritter-Zahony, R., 1911: Chaetognatha. DAS TIERREICH., 29, 1-35.

Sund, P.N., 1959: A key to the Chaetognatha of the tropical eastern Pacific Ocean. Pacif. Sei., 13(3), 269-85.

Thomson, J.M., 1947: The Chaetognatha of south-eastern Austra1ia. BuIZ. Coun. Sci. Industr. Res. Aust., 22, 1-43.

Tokioka, T., 1959: Observations on the taxonomy and distribution of Chaetognatha of the North Pacific. Publs Seto Mar. Biol. Lab., 7(3), 349-456.

Tokioka, T.R. and Pathansali, D., 1963: Another new Chaetognatha from Malay waters with a proposal of grouping some species of Sagitta into subgenera. Publs Seto Mar. Biol. Lab., 11(1), 199-223. 
TABLE 1

COMPARISON OF S. GUILERI SP. NOV. WITH S. NEGLECTA AIDA

\begin{tabular}{|c|c|c|c|}
\hline & & Alvarino (1967) & $\begin{array}{l}\text { Thomson } \\
\text { (1947) }\end{array}$ \\
\hline Length (mm) & $8-10.5$ & 8.0 & $8-10$ \\
\hline Body & Opaque and strongly built & $\begin{array}{l}\text { Firm, rigid, opaque with strong } \\
\text { muscles. }\end{array}$ & - \\
\hline Head & $\begin{array}{l}\text { Normal size, about or less than } \\
\text { the widest part of the body. }\end{array}$ & Regular or sma1l. & - \\
\hline Eyes & $\begin{array}{l}\text { Rounded, pigmented area strong, } \\
\text { dark and in the form of a 'T' } \\
\text { lying sideways with top part } \\
\text { pointing laterally. }\end{array}$ & $\begin{array}{l}\text { Roundish; pigmented area shaped like } \\
\text { a five pointed star with three large } \\
\text { arms and two small. }\end{array}$ & - \\
\hline $\begin{array}{l}\text { Intestinal } \\
\text { diverti- } \\
\text { culum }\end{array}$ & Present. & $\begin{array}{l}\text { Appear at the anterior end of the } \\
\text { digestive tract. }\end{array}$ & - \\
\hline $\begin{array}{l}\text { Corona } \\
\text { ciliata }\end{array}$ & $\begin{array}{l}\text { Absent } \\
(5 \% \text { Formalin preserved } \\
\text { specimens). }\end{array}$ & $\begin{array}{l}\text { Clearly visible, and it extends in a } \\
\text { weaving pattern from a location } \\
\text { between the eyes to midway from neck } \\
\text { to ventral ganglion. }\end{array}$ & - \\
\hline Tai1\% & $25.5-29.6$ & $26-30$ & $27-32$ \\
\hline Hooks & $6-7$ & $6-7$ & $6-8$ \\
\hline $\begin{array}{l}\text { Anterior } \\
\text { teeth }\end{array}$ & $4-5$ & 7 & $5-7$ \\
\hline $\begin{array}{l}\text { Posterior } \\
\text { teeth }\end{array}$ & $6-9$ & up to 18 & $9-16$ \\
\hline Collarette & $\begin{array}{l}\text { Present, extending from head to } \\
\text { tail as far as middle region of } \\
\text { tail fin. Relatively thicker } \\
\text { at the neck and vicinity of } \\
\text { seminal vesicle. }\end{array}$ & $\begin{array}{l}\text { Filling neck region to anterior fins } \\
\text { and as a thin layer to tip of tail. }\end{array}$ & - \\
\hline $\begin{array}{l}\text { Anterior } \\
\text { fin }\end{array}$ & $\begin{array}{l}\text { Beginning at a distance } \\
\text { (approximately } 4.0 \% \text { of the } \\
\text { body length) behind ventral } \\
\text { ganglion. Shorter than } \\
\text { posterior fin and completely } \\
\text { rayed. }\end{array}$ & $\begin{array}{l}\text { Beginning a short distance behind } \\
\text { posterior end of ventral ganglion; } \\
\text { shorter than posterior fin; no } \\
\text { rayless zone present. }\end{array}$ & - \\
\hline $\begin{array}{l}\text { Posterior } \\
\text { fin }\end{array}$ & $\begin{array}{l}\text { Long and elliptical in shape; } \\
\text { more on the tail region. } \\
\text { Posterior end terminates just } \\
\text { in front of anterior tip of } \\
\text { seminal vesicles. Completely } \\
\text { rayed. }\end{array}$ & $\begin{array}{l}\text { Beginning at a short distance behind } \\
\text { anterior fins; extending to seminal } \\
\text { vesicles; elliptical in shape; } \\
\text { located more on tail ( } 2 / 3 \text { of their } \\
\text { length) than trunk; no rayless zone. }\end{array}$ & - \\
\hline Ovaries & $\begin{array}{l}\text { Long, reaching up into the } \\
\text { neck region (one on each side). } \\
\text { ova rounded and large in one } \\
\text { row; filling the body cavity. }\end{array}$ & $\begin{array}{l}\text { Wide tubes filling trunk cavity and } \\
\text { reaching up to midway between neck } \\
\text { and ventral ganglion; ova round, } \\
\text { large and arranged in one row. }\end{array}$ & - \\
\hline $\begin{array}{l}\text { Seminal } \\
\text { vesicles }\end{array}$ & $\begin{array}{l}\text { Roundish to triangular in shape } \\
\text { protuberance at the mid-lateral } \\
\text { edge; bursts at the mid-1ateral } \\
\text { edge when mature. Nearer to } \\
\text { posterior fin. }\end{array}$ & $\begin{array}{l}\text { Touching end of posterior fins, apart } \\
\text { from tail fin; distance of seminal } \\
\text { vesicles to tail fin is about equal } \\
\text { length of vesicles; roundish with } \\
\text { anterior part more voluminous, with a } \\
\text { protuberance at anterior end at the } \\
\text { base of which a fission line is } \\
\text { visible; bursting along that line } \\
\text { extending towards lateral edge of } \\
\text { dorsal side to posterior end of } \\
\text { vesicles. }\end{array}$ & t \\
\hline
\end{tabular}


S. neglecta Aida

\begin{tabular}{|c|c|c|c|c|c|}
\hline \multirow{2}{*}{\multicolumn{2}{|c|}{$\begin{array}{l}\text { Tokioka } \\
(1959) \\
6.8-8.1\end{array}$}} & \multirow{2}{*}{$\begin{array}{l}\text { Sund (1959) } \\
7.3\end{array}$} & \multirow{2}{*}{\multicolumn{2}{|c|}{ Michael (1919) }} & \multirow{3}{*}{$\begin{array}{l}\quad \text { Michael (1911) } \\
7.9-12 \\
\text { Firm, rigid, retaining } \\
\text { its form well. }\end{array}$} \\
\hline & & & & & \\
\hline & - & $\begin{array}{l}\text { Firm, semi- } \\
\text { opaque. }\end{array}$ & & - & \\
\hline & - & - & & - & - \\
\hline & - & - & & - & - \\
\hline & - & Present. & & - & - \\
\hline & - & - & & - & - \\
\hline 28 & -32.4 & $27-31(27.4)$ & $30-33.5$ & & $26-30$ \\
\hline 6 & -8 & $6-8(7)$ & $6-7$ & & $7-9$ \\
\hline 5 & -8 & $5-7(5)$ & $4-8$ & & $3-5$ \\
\hline 13 & -18 & $13-17(17)$ & $12-16$ & & $8-11$ \\
\hline & - & Present. & & - & $\begin{array}{l}\text { Extends from neck region } \\
\text { to we } 11 \text { forward, but } \\
\text { never reaches the ventra } 1 \\
\text { ganglion. }\end{array}$ \\
\hline & - & $\begin{array}{l}\text { Starts at } \\
\text { ventral } \\
\text { ganglion. }\end{array}$ & $\begin{array}{l}\text { Three specimens out } \\
\text { studied had the ante- } \\
\text { ning } 1.0 \text { to } 1.5 \% \text { of } \\
\text { behind ventral gang } 1 \\
\text { specimens begin at } v\end{array}$ & $\begin{array}{l}\text { of } 10 \text { specimens } \\
\text { rior fin begin- } \\
\text { the body length } \\
\text { ion. Remaining } \\
\text { entral ganglion. }\end{array}$ & $\begin{array}{l}\text { Shorter and narrower than } \\
\text { posterior fin. Extends to } \\
\text { posterior end of ventra1 } \\
\text { ganglion. In form it is } \\
\text { narrowly and acutely } \\
\text { triangular. }\end{array}$ \\
\hline & - & $\begin{array}{l}\text { Reaches seminal } \\
\text { vesicles. }\end{array}$ & $\begin{array}{l}\text { Posterior end touchi } \\
\text { vesicle. }\end{array}$ & ing seminal & $\begin{array}{l}\text { Extends nearly, if not } \\
\text { quite to seminal vesicle } \\
\text { when seminal vesicles are } \\
\text { timid. Half elliptical in } \\
\text { form. }\end{array}$ \\
\hline & - & $\begin{array}{l}\text { Containing round } \\
\text { ova, extending } \\
\text { anterior to } \\
\text { posterior border } \\
\text { of anterior fin. }\end{array}$ & & - & - \\
\hline & - & Rounded. & & - & $\begin{array}{l}\text { The seminal vesicles do } \\
\text { not present such decided } \\
\text { contrast as in } S \text {. } \\
\text { sermatodentata. }\end{array}$ \\
\hline
\end{tabular}


